\title{
Beta-amyloidolysis and glutathione in Alzheimer's disease
}

J Lasierra-Cirujeda'

P Coronel $^{2}$

MJ Aza ${ }^{3}$

M Gimeno ${ }^{2}$

'CM Hematológico SC, Logroño, La Rioja, Spain; ${ }^{2}$ Tedec-Meiji Farma, SA, Alcalá de Henares, Madrid, Spain; ${ }^{3}$ Pharmaceutical Act, Ministry of Health, Regional Government, La Rioja, Spain
Correspondence: J Lasierra-Cirujeda C/Vara del Rey II, I A 2600 I Logroño, La Rioja, Spain

Tel +34 94I 223565

Fax +34 94I 223565

Email hematol@telefonica.net
This article was published in the following Dove Press journal:

Journal of Blood Medicine

12 April 2013

Number of times this article has been viewed
Abstract: In this review, we hypothesized the importance of the interaction between the brain glutathione (GSH) system, the proteolytic tissue plasminogen activator (t-PA)/plasminogen/ plasmin system, regulated by plasminogen activator inhibitor (PAI-1), and neuroserpin in the pathogenesis of Alzheimer's disease. The histopathological characteristic hallmark that gives personality to the diagnosis of Alzheimer's disease is the accumulation of neurofibroid tangles located intracellularly in the brain, such as the protein tau and extracellular senile plaques made primarily of amyloidal substance. These formations of complex etiology are intimately related to GSH, brain protective antioxidants, and the proteolytic system, in which t-PA plays a key role. There is scientific evidence that suggests a relationship between aging, a number of neurodegenerative disorders, and the excessive production of reactive oxygen species and accompanying decreased brain proteolysis. The plasminogen system in the brain is an essential proteolytic mechanism that effectively degrades amyloid peptides ("beta-amyloidolysis") through action of the plasmin, and this physiologic process may be considered to be a means of prevention of neurodegenerative disorders. In parallel to the decrease in GSH levels seen in aging, there is also a decrease in plasmin brain activity and a progressive decrease of t-PA activity, caused by a decrease in the expression of the t-PA together with an increase of the PAI-1 levels, which rise to an increment in the production of amyloid peptides and a lesser clearance of them. Better knowledge of the GSH mechanism and cerebral proteolysis will allow us to hypothesize about therapeutic practices.

Keywords: glutathione, Alzheimer's disease, t-PA, PAI-1, plasminogen

\section{Introduction}

Sporadic or common Alzheimer's disease (AD) is a chronic process of complex etiology, without any existing effective treatment, with aging being the main etiological factor of universal risk.

The histopathological characteristic that gives personality to the diagnosis of AD is the accumulation of neurofibroid tangles located intracellularly in the brain, such as protein $\operatorname{tau}^{1-6}$ and senile plaques with extracellular amyloid beta $(\mathrm{Ab})$ substance. ${ }^{7-13}$ These deposits are produced as a consequence of a biological disorder in their production and elimination/clearance from the brain. ${ }^{10,13-17}$ These formations of complex etiology are intimately related to glutathione (GSH), brain protective antioxidants, and proteolysis, in which tissue plasminogen activator (t-PA) plays a key role. ${ }^{18,19}$

Our review suggests that GSH may play an essential role in the physiopathology of the different components of the proteolytic mechanisms in the brain, and focuses on its relation to t-PA and the plasminogen/plasmin system. 


\section{Brain GSH}

GSH (L-gamma-glutamyl-L-cysteinylglycine) is a tripeptide present in large quantities in all mammal cells and in small amounts extracellularly, ${ }^{20-22}$ being mainly located in the cytosol, mitochondria, and endoplasmic reticulum. ${ }^{23}$ It plays a very important role in many biological processes involved in organism homeostasis, most notably, in neutralizing the free radicals that produce reactive oxygen species (ROS) (due to its great antioxidant activity), ${ }^{20,24-28}$ since oxidation is a basic process in the genesis of neurodegenerative disorders. ${ }^{29}$

GSH is the most important component of the antioxidant mechanism of the brain. ${ }^{30}$ It has a relatively homogeneous distribution in rat brains, ${ }^{31-33}$ reaching its highest levels in the brain cortex, corpus striatum, and the glia ${ }^{31,34}$ but it diminishes significantly with aging. ${ }^{32,34,35}$ GSH levels in neuronal cells are lower than in glia cells. ${ }^{36-38}$ This difference can be due to a smaller reserve of precursors for the GSH synthesis, especially of cysteine.

In studies of brain cells, the concentration of GSH in different neuronal cells has been found to vary considerably. ${ }^{39,40}$ Likewise, the GSH concentration in astroglia cell cultures has also been found to vary widely. ${ }^{39,41,42}$ Other studies have shown lower GSH concentration levels in neurons than in astrocytes, ${ }^{39,43}$ with the concentration of endogenous neuronal GSH ten times lower than in astrocytes. ${ }^{44}$ The separation of neurons and glia cells in cocultures and then their later culture has shown a significantly decreased level of neuronal GSH whereas this remained constant in astroglia cells. ${ }^{43}$ This difference in GSH levels between astrocytes and neurons was observed in the cortex; nevertheless, the concentrations are very similar in other parts of the brain, like the midbrain and the stratium. ${ }^{45}$ It is possible that this presence and distribution in the brain is due to cellular specialization that confers a great capacity to generate free radicals, as a consequence of being an organ with high oxygen requirement $(20 \%$ of the total consumption of the organism, in spite of being less than $2 \%$ of the body weight in human adults). ${ }^{46}$

Astrocytes protect neurons against the toxicity of free radicals by increasing their GSH levels, by means of the transfer of sulfated amino acids or peptides as precursors (mainly cysteine and the dipeptide CysGly). ${ }^{30,44,47-49} \mathrm{An}$ increase in cellular GSH concentration makes the neurons more resistant to cytotoxic injuries. ${ }^{50-52}$

Many cerebral functions are altered as a consequence of decrease in intra- and extracellular levels of GSH. ${ }^{53}$ This decrease can be due to either the inhibition of its synthesis or its consumption in the conjugation with exogenous compounds. ${ }^{24,54}$ The progressive decrease of GSH levels resulting from aging and related illnesses, is of great interest for investigators. ${ }^{55,56}$ The decrease of GSH levels has been detected not only in humans, but also in lesser animals, such as rodents and insects. ${ }^{57}$ The decrease found with aging is linked to an increase of ROS. ${ }^{58}$ There is scientific evidence of a relationship between aging and a number of neurodegenerative processes due to the excessive production of free radicals and the imbalance between the oxidant species and antioxidant defenses. ${ }^{59-61}$

Buthionine sulfoximine (S-(n-butyl) homocysteine sulfoximine) (BSO), a selective and potent inhibitor of the gamma-glutamylcysteine synthetase, ${ }^{24,62}$ has been administered in previous investigations. BSO inhibits GSH biosynthesis and causes depletion of cellular GSH levels. ${ }^{21,22}$ In rats, the same GSH decrease has also been achieved with the administration of diethyl maleate - the diethyl maleate reacts with GSH, causing the formation of conjugated GSH, which is then excreted. ${ }^{31,62-64}$

The effect of pharmacological depletion of cerebral GSH following exposure to BSO and diethyl maleate, in cellular cultures or after their administration to animals, has been studied over the last 20 years. From an experimental point of view, the administration of BSO by systemic route to adults has not been very effective in producing GSH depletion in the brain, ${ }^{65}$ being effective only in newborn rats or mice, where it was facilitated by the immaturity of the blood-brain barrier (BBB) ${ }^{66}$ Low levels in adult animals have been achieved using a direct intracerebroventricular ${ }^{65,67}$ administration of BSO by means of stereotaxic technique ${ }^{68}$ or by intrathecal administration. ${ }^{69}$

The decrease of GSH levels in the brain of newborn rats has been shown to frequently lead the animal to a fatal situation, as a consequence of the accumulation of hydrogen peroxide and subsequent mitochondrial lesion, thus showing the great metabolic importance of GSH. ${ }^{66,70}$ Decrease in the number of cerebral mitochondria has also been observed ${ }^{71}$ as well as the reduction in enzymatic activity of GSH reductase..$^{72}$ In investigations of cerebral ischemia, it has been observed that GSH depletion exacerbates cortical infarction and edemas after ischemia, due to an increasing presence of ROS. $^{73}$ In cultures of mesencephalic cells, incubation with $\mathrm{BSO}$ has caused a significant reduction of GSH, resulting in a loss of the integrity of the membrane and cellular death, ${ }^{74,75}$ after the loss of mitochondrial GSH. ${ }^{76}$ The depletion of cerebral GSH has also been found to modify the interaction between astrocytes and neurons, diminishing the neuronal protection against oxidant agents. ${ }^{44,77}$

Given the GSH decrease that is progressively produced with aging, ${ }^{57,60,78,79}$ we cannot discard the hypothesis that 
a defect in the mechanism of antioxidant cellular defense can be the silent trigger of the neurodegenerative process and neuronal death. ${ }^{72}$ It may be that an imbalance in the equilibrium between the formation of free radicals and their neutralization (oxidation-reduction) leads to a situation of oxidative stress with great organic risk that can be associated with neurodegenerative illnesses, ${ }^{73,79,80}$ including, most often, Parkinson's disease ${ }^{25}$ and AD. ${ }^{33,74}$

\section{Fibrinolytic activity and GSH}

In 1959, Todd $^{81}$ devised a histochemical fibrin slide technique with which he demonstrated the existence of areas of lysis in vascular walls that were related to the presence of the activators of fibrinolysis. Using immunohistochemical methods, it was revealed that t-PA was present in the blood vessels of most organs and that it was synthesized by endothelial cells. ${ }^{82,83}$

More than 20 years ago ${ }^{62}$ it was reported that the pharmacological effect of administration of BSO or diethyl maleate in rabbits is a significant decrease in GSH levels, accompanied by the inhibition of fibrinolytic activity important for the fibrin plate. This inhibition of plasmin activity results from a decrease in the liberation of t-PA at the cellular level and a significant increase in its inhibitor, plasminogen activator inhibitor (PAI-1), and occurs without any modification in the normal values of alpha-2 antiplasmin. These results lead us to consider that GSH could play an essential role in regulation of the different components of the fibrinolytic system.

Following an administration of BSO, to rabbits at a dose of $4.5 \mathrm{mmol} / \mathrm{kg}$ body weight liver, it was seen that GSH concentrations were reduced, with the greatest decrease (51\%) occurring 7 hours after administration and with values that remained lowered after 24 hours; however, at 3 days posttreatment, GSH concentrations did not significantly differ from those in the control groups. Treatment with diethyl maleate, at a dose of $3.2 \mathrm{mmol} / \mathrm{kg}$ body weight, also induced a significant reduction in hepatic GSH levels that were $54 \%$ lower than those of the controls, after 45 minutes. GSH concentrations in the aortic arch were equally reduced $(0.24 \pm 0.05 \mu \mathrm{mol} / \mathrm{g}$ liver and $0.20 \pm 0.04 \mu \mathrm{mol} / \mathrm{g}$ liver $)$ 7 hours after BSO or 45 minutes after diethyl maleate were administered, respectively; concentration in the control group was $0.33 \pm 0.04 \mu \mathrm{mol} / \mathrm{g}$ liver $){ }^{62}$

A study of the fibrinolytic activity in the aortic arch revealed an extensive area of lysis in the endothelial wall in the control rabbit groups. ${ }^{62}$ Following an administration of BSO, fibrinolysis was inhibited (Figure 1A and B) and only reappeared 3 days later. Intraperitoneal injection of
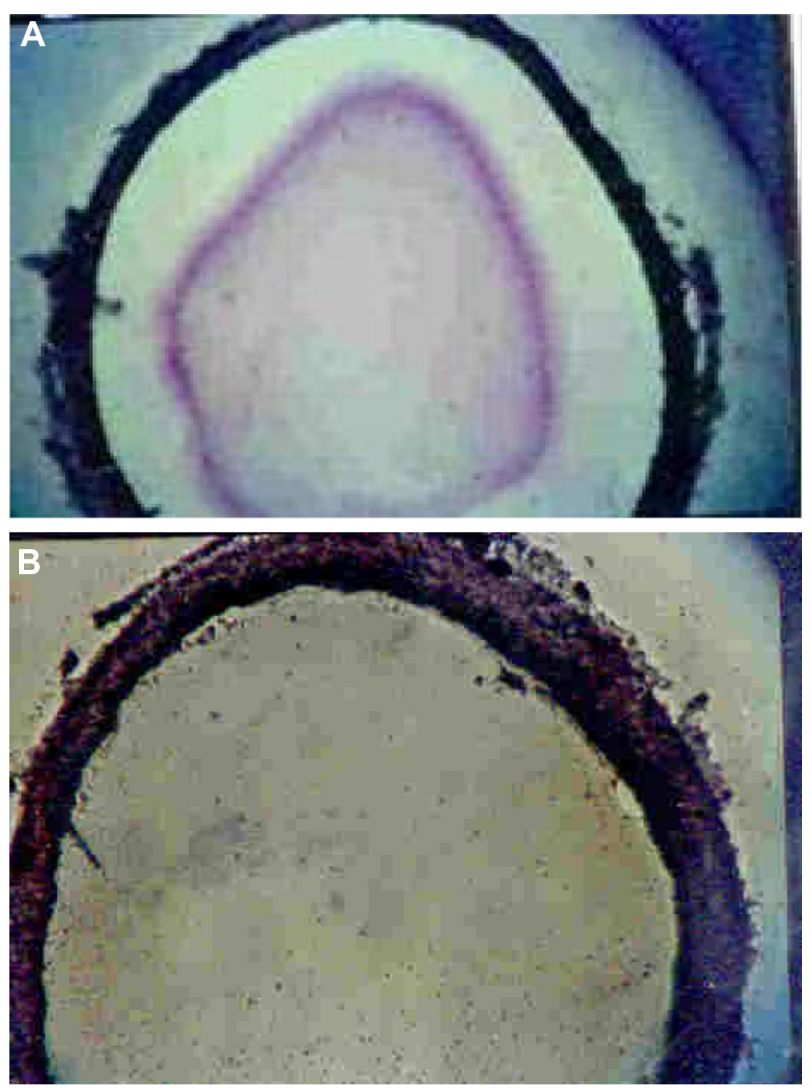

Figure I Inhibition of fibrinolytic activity by BSO, on arterial walls in rabbits. Photomicrographs of $30 \mu \mathrm{m}$ cross sections of the aortic arch that were incubated with fibrinogen, plasminogen, and human thrombin and stained with Harris' hematoxylin $(\times 40)$. (A) Fibrinolytic activity of the aortic arch reveals an extensive area of lysis under the endothelial wall. (B) Seven hours after BSO administration, the inhibited fibrinolysis activity could be attributed to a lower release of t-PA. Note: Plasma t-PA levels were decreased following administration of BSO and only reappeared 3 days later, when the level of plasma glutathione was also normal. ${ }^{62}$ Abbreviations: BSO, buthionine sulfoximine; t-PA, tissue plasminogen activator.

diethyl maleate also induced significant inhibition activity in the aorta.

Another similar study of the blood components in the fibrinolytic system revealed a significant reduction in t-PA activity (-29\% and $-22 \%)$ and a significant increase in PAI-1 activity $(+61 \%$ and $+27 \%)$, following a treatment with BSO or diethyl maleate, respectively. Alpha-2-antiplasmin was not significantly affected by the administration of either GSHdepleting agents. ${ }^{62}$

\section{Plasminogen/plasmin systems in AD}

The plasminogen system is a group of mechanisms whose interaction leads to the production of a protease involved in degrading substrates and avoiding their accumulation, and which is regulated by specific inhibitors. ${ }^{84}$ The cerebral plasminogen system does not differ from the systemic plasminogen system, as all the constituents of the systemic mechanism are present in the brain. ${ }^{85}$ 
$\mathrm{Ab}$ is the target for proteolytic degradation by several proteases known as the $\mathrm{Ab}$-degrading proteases..$^{86}$ Among the different, best-known Ab-degrading proteases are: neprilysin, ${ }^{12,87,92}$ insulin-degrading enzyme, ${ }^{93,94}$ endothelin converting enzyme, ${ }^{93,95,96}$ matrix metalloprotease, ${ }^{97-99}$ and plasmin. ${ }^{100-102}$ Of greatest interest to the study of Ab clearance and elimination through the BBB, are neprilysin $\sin ^{79,88,89,103,104}$ and plasmin. ${ }^{105}$

The plasminogen system is an essential proteolytic mechanism that, by the action of plasmin, effectively degrades $\mathrm{Ab}$ peptides (beta-amyloidolysis), prompting us to consider this physiologic process as a preventive mechanism of neurodegenerative processes. ${ }^{19,106}$ Nevertheless, the primary substrate of degradation by plasmin in the brain is not very well known. ${ }^{107}$ Plasmin activity is diminished in the hippocampus and cortex of patients with $\mathrm{AD} .{ }^{12,108}$ As mentioned earlier, the excessive production and lack of clearance of the peptide $A b$ creates the accumulation of senile plaques that define $\mathrm{AD} .{ }^{18}$

A decrease in brain plasmin activity leads to a smaller clearance and an increase in the $\mathrm{Ab}$ deposits. ${ }^{15,16}$ Experimental studies in mice have shown an increase of $\mathrm{Ab}$ material deposits and an increase of PAI- 1 in the process of AD. ${ }^{88,89}$ Therefore, the inhibition of the t-PA by the PAI- 1 facilitates the accumulation of $\mathrm{Ab}$ material and slows its degradation and later clearance; very important mechanisms in the genesis of AD. ${ }^{18,102}$

For investigators, t-PA plays a significant role in the physiopathology of the central nervous system (CNS). ${ }^{109}$ At the CNS level, t-PA has a specific inhibitor, neuroserpin (NSP), which is found in those regions where t-PA is present. The coexpression of NSP and t-PA in the same regions of the brain suggests that NSP is a likely regulator of t-PA activity within the CNS. This complex t-PA/NSP contrasts with the formation of long-lasting, phyiologically irreversible complexes between t-PA and PAI-1 (due solely to differences in affinities of t-PA for PAI-1 versus NSP). ${ }^{110}$

In some studies, neurotoxicity has been attributed to the plasminogen system. ${ }^{11-120}$ In certain pathologies, such as in ischemia and cytotoxicity, activation of the plasminogen system occurs by t-PA, generating plasmin, which in turn, degrades the extracellular matrix by action on the laminin, producing neuronal loss. ${ }^{121}$ Other studies cast doubt on this action of t-PA, demonstrating that direct infusion does not lead to neuronal loss. ${ }^{114}$ Conversely, other results have conferred on t-PA a protective characteristic against cellular injury (both in vitro and in vivo) ${ }^{122}$ and considered it to be a regulator of vascular tone and permeability ${ }^{118}$ as well as a regulator of the $\mathrm{BBB}^{128}$ and a mediator in neuronal connection (synaptic plasticity). ${ }^{124,125}$ t-PA has been considered to have effects that are not related to its ability to activate plasminogen. For example, in mice lacking t-PA, neurons were found to be resistant to the damage caused by strokes. ${ }^{116}$ Further, t-PA increases microglia activation, without requiring any proteolytic activity. ${ }^{126}$ To sum up, t-PA is considered as a cerebral mediator, exercising both proteolytic and nonproteolytic actions, at a metabolic, functional, or morphological level. ${ }^{127}$

The relationship between GSH and the plasminogen system is of great importance for cerebral function. The pharmacological depletion of GSH produces a significant inhibition of the plasminogen mechanism, secondarily inhibiting the generation of plasmin. As indicated previously, the lack of plasminic activity in the brain leads to the accumulation of $\mathrm{Ab}$ peptides and to the formation of the extracellular plaques and intracellular tangles, found in AD. ${ }^{18,106}$ PAI-1 increases in different pathologies associated with GSH depletion and oxidative stress. ${ }^{128}$

Throughout aging, normal mice have been shown to experience a progressive decrease of t-PA activity. ${ }^{129,130} \mathrm{In}$ parallel, lower levels of GSH have been found in the cortex, cerebellum, striatum, thalamus, and hippocampus (although hepatic levels remain normal). ${ }^{35,112,129}$ This decrease in t-PA activity found in normal mice, is due to a decrease in the expression of t-PA and to an increase in the production of PAI-1, carrying with this an increase in the production of Ab peptides. ${ }^{11,129,130}$ The same results have been found in the cerebral tissue of patients with sporadic $\mathrm{AD}$, where a negative correlation between proteolytic activity and the levels of $\mathrm{Ab}$ peptides has been observed. ${ }^{15}$

Clinically, there is evidence to suggest that cognitive status can be improved with decreases in the concentration of $\mathrm{Ab}$ peptide in the cerebrospinal fluid, and that short- and long-term resistance to cognitive deterioration can be achieved with the administration of heparan sulfate-dermatan sulfate (sulodexide) (a glycosaminoglycan drug that crosses the BBB and acts by inhibiting PAI-1 and activating t-PA, with an accompanying increase in proteolytic activity). ${ }^{131-143}$ In a study conducted by us, ${ }^{144}$ two groups of patients were treated with sulodexide or with acenocoumarol. Follow up of these patients after 6 years revealed that patients treated with sulodexide experienced significantly less deterioration of cognitive status compared with the group treated with acenocumarol (Lasierra-Cirujeda, personal communication October, 2011).

In animal models as well as in clinical trials in humans, an enteral or parenteral supply of nutrients, including cysteine, methionine, N-acetyl-cysteine (NAC), and L-2- 
oxo-thiazolidine, were found to be suitable precursors for the synthesis of GSH and subsequently led to an increase in the intracellular level of GSH. ${ }^{28,51,145-147}$ Normalization of GSH levels improves the proteolytic cerebral capacity. After the administration of GSH to patients with diabetes mellitus type 2 , a significant reduction of plasma PA-1 levels, and an increment in the concentration of GSH in blood red cells were found. These results suggest the usefulness of GSH in the improvement of the plasminogen system. ${ }^{148-150}$

Finally, the supply of GSH precursors and the resulting increase in the antioxidant GSH has been found to promote cellular resistance to oxidative stress, by leading to an intraand extracellular proteolytic improvement caused by both the decrease in PAI-1 and the increased clearance of the cerebral Ab proteins. ${ }^{150,151}$

In this review, we hypothesized the importance of the interaction between cerebral GSH and plasminogen systems in neurodegenerative diseases. In summary, the cerebral GSH and plasminogen systems are essential biological processes that combat the neurodegenerative processes that occur more significantly with advancing age. With knowledge of the physiopathology of neurodegenerative processes, both of these systems can be pharmacological targets, providing reason for hope of prevention of neurodegenerative diseases such as AD.

\section{Disclosure}

The authors report no conflicts of interest in this work.

\section{References}

1. Delacourte A, Defossez A. Alzheimer's disease: Tau proteins, the promoting factors of microtubule assembly, are major components of paired helical filaments. J Neurol Sci. 1986;76(2-3):173-186.

2. Kosik KS, Joachim CL, Selkoe DJ. Microtubule-associated protein tau (tau) is a major antigenic component of paired helical filament in Alzheimer disease. Proc Natl Acad Sci U SA. 1986;83(11):4044-4048.

3. Flament S, Delacourte A, Hémon B, Défossez A. Characterization of two pathological tau protein, variants in Alzheimer brain cortices. J Neurol Sci. 1989;92(2-3):133-141.

4. Lee VM, Balin BJ, Otvos L Jr, Trojanowski JQ. A68: a major subunit of paired helical filaments and derivatized forms of normal Tau. Science. 1991;251(4994):675-678.

5. Hasegawa M, Morishima-Kawashima M, Takio K, Suzuki M, Titani K, Ihara Y. Protein sequence and mass spectrometric analyses of tau in the Alzheimer's disease brain. J Biol Chem. 1992;267(24):17047-17054.

6. Sergeant N, Bussière T, Vermersch P, Lejeune JP, Delacourte A. Isoelectric point differentiates PHF-tau from biopsy-derived human brain tau proteins. Neuroreport. 1995;6(16):2217-22120.

7. Glenner GG, Wong CW. Alzheimer's disease: initial report of the purification and characterization of a novel cerebrovascular amyloid protein Biochem Biophys Res Commun. 1984;120(3):885-890.

8. Masters CL, Simms G, Weinman NA, Multhaup G, McDonald BL, Beyreuther K. Amyloid plaque core protein in Alzheimer disease and Down syndrome. Proc Natl Acad Sci U S A. 1985;82(12):4245-4249.

9. Selkoe DJ. Translating cell biology into therapeutic advances in Alzheimer's disease. Nature. 1999;399(Suppl 6738):S23-S31.
10. Selkoe DJ. Towards a comprehensive theory for Alzheimer's disease. Hypothesis: Alzheimer's disease is caused by the cerebral accumulation and cytotoxicity of amyloid beta-protein. Ann NY Acad Sci. 2000; 924:17-25.

11. Selkoe DJ. Clearing the brain's amyloid cobwebs. Neuron. 2001; 32(2):177-180.

12. Iwata N, Tsubuki S, TakakiY, et al. Metabolic regulation of brain Abeta by neprilysin. Science. 2001;292(5521):1550-1552.

13. Hardy J, Selkoe DJ. The amyloid hypothesis of Alzheimer's disease: progress and problems on the road to therapeutics. Science. 2002;297(5580):353-356.

14. Saido TC. Alzheimer's disease as proteolytic disorders: anabolism and catabolism of beta-amyloid. Neurobiol Aging. 1998;19(Suppl 1): S69-S75.

15. Zlokovic BV. Clearing amyloid through the blood-brain barrier. J Neurochem. 2004;89(4):807-811.

16. Tanzi RE, Moir RD, Wagner SL. Clearance of Alzheimer's Abeta peptide: the many roads to perdition. Neuron. 2004;43(5):605-608.

17. Holtzman DM, Zlokovic B. Role of A $\beta$ transport and clearance in the pathogenesis and treatment of Alzheimer's disease. In: Sisodia SS, Tanzi RE, editors. Alzheimer's Disease: Advances in Genetics, Molecular and Cellular Biology. New York: Springer; 2007:179-198.

18. Melchor JP, Pawlak R, Strickland S. The tissue plasminogen activator-plasminogen proteolytic cascade accelerates amyloid-beta (Abeta) degradation and inhibits Abeta-induced neurodegeneration. J Neurosci. 2003;23(26):8867-8871.

19. De Strooper B. Proteases and proteolysis in Alzheimer disease: a multifactorial view on the disease process. Physiol Rev. 2010;90(2): 465-494.

20. Jones DP. Redox potential of GSH/GSSG couple: assay and biological significance. Methods Enzymol. 2002;348:93-112.

21. Griffith OW. Mechanism of action, metabolism, and toxicity of buthionine sulfoximine and its higher homologs, potent inhibitors of glutathione synthesis. J Biol Chem. 1982;257(22):13704-13712.

22. Meister A, Anderson ME. Glutathione. Annu Rev Biochem. 1983;52: 711-760.

23. Lu SC. Regulation of glutathione synthesis. Curr Top Cell Regul. 2000;36:95-116.

24. Griffith OW, Meister A. Potent and specific inhibition of glutathione synthesis by buthionine sulfoximine (S-n-butyl homocysteine sulfoximine). J Biol Chem. 1979;254(16):7558-7560.

25. Bains JS, Shaw CA. Neurodegenerative disorders in humans: the role of glutathione in oxidative stress-mediated neuronal death. Brain Res Brain Res Rev. 1997;25(3):335-358.

26. Lu SC. Regulation of hepatic glutathione synthesis: current concepts and controversies. FASEB J. 1999;13(10):1169-1183.

27. Griffith OW. Biologic and pharmacologic regulation of mammalian glutathione synthesis. Free Radic Biol Med. 1999;27(9-10):922-935.

28. Wu G, Fang YZ, Yang S, Lupton JR, Turner ND. Glutathione metabolism and its implications for health. $J$ Nutr. 2004;134(3):489-492.

29. Butterfield DA, Perluigi M, Sultana R. Oxidative stress in Alzheimer's disease brain: new insights from redox proteomics. Eur J Pharmacol. 2006;545(1):39-50.

30. Dringen R, Gutterer JM, Hirrlinger J. Glutathione metabolism in brain metabolic interaction between astrocytes and neurons in the defense against reactive oxygen species. Eur J Biochem. 2000;267(16):4912-4916.

31. Philbert MA, Beiswanger CM, Waters DK, Reuhl KR, Lowndes HE. Cellular and regional distribution of reduced glutathione in the nervous system of the rat: histochemical localization by mercury orange and o-phthaldialdehyde-induced histofluorescence. Toxicol Appl Pharmacol. 1991;107(2):215-227.

32. Zhu Y, Carvey PM, Ling Z. Age-related changes in glutathione and glutathione-related enzymes in rat brain. Brain Res. 2006;1090(1): $35-44$.

33. Liu H, Wang H, Shenvi S, Hagen TM, Liu RM. Glutathione metabolism during aging and in Alzheimer disease. Ann NY Acad Sci. 2004;1019: $346-349$. 
34. Hjelle OP, Chaudhry FA, Ottersen OP. Antisera to glutathione: characterization and immunocytochemical application to the rat cerebellum. Eur J Neurosci. 1994;6(5):793-804.

35. Ravindranath V, Shivakumar BR, Anandatheerthavarada HK. Low glutathione levels in brain regions of aged rats. Neurosci Lett. 1989;101(2):187-190

36. Makar TK, Nedergaard M, Preuss A, Gelbard AS, Perumal AS, Cooper AJ. Vitamin E ascorbate, glutathione, glutathione disulfide, and enzymes of glutathione metabolism in cultures of chick astrocytes and neurons: evidence that astrocytes play an important role in antioxidative processes in the brain. J Neurochem. 1994;62(1):45-53.

37. Cooper AJL. Glutathione in the brain: disorders of glutathione metabolism. In: Rosenberg RN, Prusiner SB, DiMauro S, Barchi RL, Kunk LM, editors. The Molecular and Genetic Basis of Neurological Disease. Boston: Butterworth-Heinemann; 1997:1195-1230.

38. Keelan J, Allen NJ, Antcliffe D, Pal S, Duchen MR. Quantitative imaging of glutathione in hippocampal neurons and glia in culture using monochlorobimane. J Neurosci Res. 2001;66(5):873-884.

39. Raps SP, Lai JC, Hertz L, Cooper AJ. Glutathione is present in high concentrations in cultured astrocytes but not in cultured neurons. Brain Res. 1989;493(2):398-401.

40. Pileblad E, Eriksson PS, Hansson E. The presence of glutathione in primary neuronal and astroglial cultures from rat cerebral cortex and brain stem. J Neural Transm Gen Sect. 1991;86(1):43-49.

41. Devesa A, O’Connor JE, Garciá C, Puertes IR, Viña JR. Glutathione metabolism in primary astrocyte cultures: flow cytometric evidence of heterogeneous distribution of GSH content. Brain Res. 1993;618(2):181-189.

42. Dringen R, Hamprecht B. Glutathione content as an indicator for the presence of metabolic pathways of amino acids in astroglial cultures. J Neurochem. 1996;67(4):1375-1382.

43. Sagara JI, Miura K, Bannai S. Maintenance of neuronal glutathione by glial cells. J Neurochem. 1993;61(5):1672-1676.

44. Byrd AS, Sikorska M, Walker PR, Sandhu JK. Effects of glutathione depletion on the viability of human NT2-derived neuronal and astroglial cultures. Neuron Glia Biol. 2004;1(4):317-326.

45. Langeveld $\mathrm{CH}$, Schepens E, Jongenelen CA, et al. Presence of glutathione immunoreactivity in cultured neurones and astrocytes. Neuroreport. 1996;7(11):1833-1836.

46. Clarke DD, Sokoloff L. Circulation and energy metabolism of the brain. In: Siegel GJ, Agranoff BW, Albers RW, Fisher SK, Uhler MD, editors. Basic Neurochemistry: Molecular, Cellular and Medical Aspects, 6th ed. Philadelphia: Lippincott-Raven; 1999:637-669.

47. Kranich O, Dringen R, Sandberg M, Hamprecht B. Utilization of cysteine and cysteine precursors for the synthesis of glutathione in astroglial cultures: preference for cystine. Glia. 1998;22(1):11-18.

48. Dringen R, Pfeiffer B, Hamprecht B. Synthesis of the antioxidant glutathione in neurons: supply by astrocytes of CysGly as precursor for neuronal glutathione. J Neurosci. 1999;19(2):562-569.

49. Dringen R, Hirrlinger J. Glutathione pathways in the brain. Biol Chem. 2003;384(4):505-516.

50. Barkats M, Millecamps S, Abrioux P, Geoffroy MC, Mallet J. Overexpression of glutathione peroxidase increases the resistance of neuronal cells to Abeta-mediated neurotoxicity. $J$ Neurochem. 2000;75(4):1438-1446.

51. Pocernich CB, La Fontaine M, Butterfield DA. In-vivo glutathione elevation protects against hydroxyl free radical-induced protein oxidation in rat brain. Neurochem Int. 2000;36(3):185-191.

52. James SJ, Slikker W 3rd, Meinyk S, New E, Pogribna M, Jernigan S. Thimerosal neurotoxicity is associated with glutathione depletion: protection with glutathione precursors. Neurotoxicology. 2005;26(1):1-8.

53. Aoyama K, Suh SW, Hamby AM, et al. Neuronal glutathione deficiency and age-dependent neurodegeneration in the EAAC1 deficient mouse. Nat Neurosci. 2006;9(1):119-126.

54. Zhu M, Bowden GT. Molecular mechanism(s) for UV-B irradiationinduced glutathione depletion in cultured human keratinocytes. Photochem Photobiol. 2004;80(2):191-196.
55. Halliwell B, Gutteridge J. Free Radicals in Biology and Medicine, 4th ed. Oxford: Oxford University Press; 2007.

56. Hartman D. Free radical theory of aging: Alzheimer's disease pathogenesis. Age. 1995;18(3):97-119.

57. Sohal RS, Weindruch R. Oxidative stress, caloric restriction, and aging. Science. 1996;273(5271):59-63.

58. Ames BN, Shigenaga MK, Hagen TM. Oxidants, antioxidants, and the degenerative diseases of aging. Proc Natl Acad Sci USA. 1993;90(17): 7915-7922.

59. Schulz JB, Lindenau J, Seyfried J, Dichgans J. Glutathione, oxidative stress and neurodegeneration. Eur J Biochem. 2000;267(16):4904-4911.

60. Mecocci P, MacGarvey U, Kaufman AE, et al. Oxidative damage to mitochondrial DNA shows marked age-dependent increases in human brain. Ann Neurol. 1993;34(4):609-616.

61. Mecocci P, Beal MF, Cecchetti R, et al. Mitochondrial membrane fluidity and oxidative damage to mitochondrial DNA in aged and AD human brain. Mol Chem Neuropathol. 1997;31(1):53-64.

62. Lasierra J, Aza MJ, Collado PS, González J, Esteller A. Inhibition of fibrinolysis by cellular glutathione depletion in the rabbit. Thromb Res. 1989;53(4):347-355.

63. Aza MJ, Gonzalez J, Esteller A. Effect of diethyl maleate pretreatment on biliary excretion and choleretic action of sulfobromophthalein in rats. Arch Int Pharmacodyn Ther. 1986;281(2):321-330.

64. Kaplowitz N, Aw TY, Ookhtens M. The regulation of hepatic glutathione. Annu Rev Pharmacol Toxicol. 1985;25:715-744.

65. Masukawa T, Sai M, Tochino Y. Methods for depleting brain glutathione. Life Sci. 1989;44(6):417-424.

66. Jain A, Mårtensson J, Stole E, Auld PA, Meister A. Glutathione deficiency leads to mitochondrial damage in brain. Proc Natl Acad Sci U S A. 1991;88(5):1913-1917.

67. Pileblad E, Magnusson T. Intracerebroventricular administration of L-buthionine sulfoximine: a method for depleting brain glutathione. J Neurochem. 1989;53(6):1878-1882.

68. Pellegrino LJ, Pellegrino AS, Cushman AJ. A Stereotaxic Atlas of the Rat Brain, 2nd ed. New York: Plenum Press; 1979.

69. Shivakumar BR, Ravindranath V. Selective modulation of glutathione in mouse brain regions and its effect on acrylamide-induced neurotoxicity. Biochem Pharmacol. 1992;43(2):263-269.

70. Lee M, Cho T, Jantaratnotai N, Wang YT, McGeer E, McGeer PL. Depletion of GSH in glial cells induces neurotoxicity: relevance to aging and degenerative neurological diseases. FASEB J. 2010;24(7):2533-2545.

71. Mãrtensson J, Meister A. Glutathione deficiency decreases tissue ascorbate levels in newborn rats: ascorbate spares glutathione and protects. Proc Natl Acad Sci U S A. 1991;88(11):4656-4660.

72. Barker JE, Heales SJ, Cassidy A, Bolaños JP, Land JM, Clark JB. Depletion of brain glutathione results in a decrease of glutathione reductase activity; an enzyme susceptible to oxidative damage. Brain Res. 1996;716(1-2):118-122.

73. Mizui T, Kinouchi H, Chan PH. Depletion of brain glutathione by buthionine sulfoximine enhances cerebral ischemic injury in rats. Am J Physiol. 1992;262(2 Pt 2):H313-H317.

74. Mytilineou C, Leonardi EK, Radcliffe P, et al. Deprenyl and desmethylselegiline protect mesencephalic neurons from toxicity induced by glutathione depletion. J Pharmacol Exp Ther. 1998;284(2):700-706.

75. Li Y, Maher P, Schubert D. A role for 12-lipoxygenase in nerve cell death caused by glutathione depletion. Neuron. 1997;19(2):453-463.

76. Meister A. Glutathione deficiency produced by inhibition of its synthesis, and its reversal; applications in research and therapy. Pharmacol Ther. 1991;51(2):155-194.

77. Sandhu JK, Gardaneh M, Iwasiow R, et al. Astrocyte-secreted GDNF and glutathione antioxidant system protect neurons against 6OHDA cytotoxicity. Neurobiol Dis. 2009;33(3):405-414.

78. Cudkowicz ME, Sexton PM, Ellis T, et al. The pharmacokinetics and pharmaco-dynamics of Procysteine in amyotrophic lateral sclerosis. Neurology. 1999;52(7):1492-1494.

79. Christen Y. Oxidative stress and Alzheimer disease. Am J Clin Nutr. 2000;71(2):621S-629S. 
80. Lovell MA, Xie C, Markesbery WR. Decreased glutathione transferase activity in brain and ventricular fluid in Alzheimer's disease. Neurology. 1998;51(6):1562-1566.

81. Todd AS. The histological localisation of fibrinolysin activator. J Pathol Bacteriol. 1959;78:281-283.

82. Loskutoff DJ, Edgington TE. Synthesis of a fibrinolytic activator and inhibitor by endothelial cells. Proc Natl Acad Sci U SA. 1977;74(9): 3903-3907.

83. Larsson A, Astedt B. Immunohistochemical localisation of tissue plasminogen activator and urokinase in the vessel wall. J Clin Pathol. 1985;38(2):140-145.

84. Collen D. The plasminogen (fibrinolytic) system. Thromb Haemost. 1999;82(2):259-270.

85. Hino $\mathrm{H}$, Akiyama $\mathrm{H}$, Iseki $\mathrm{E}$, et al. Immunohistochemical localization of plasminogen activator inhibitor-1 in rat and human brain tissues. Neurosci Lett. 2001;297(2):105-108.

86. Saido T, Leissring MA. Proteolytic degradation of amyloid b-protein. Cold Spring Harb Perspect Med. 2012;2(6):a006379.

87. Howell S, Nalbantoglu J, Crine P. Neutral endopeptidase can hydrolyze beta-amyloid(1-40) but shows no effect on beta-amyloid precursor protein metabolism. Peptides. 1995;16(4):647-652.

88. Shirotani K, Tsubuki S, Iwata N, et al. Neprilysin degrades both amyloid beta peptides $1-40$ and 1-42 most rapidly and efficiently among thiorphan- and phosphoramidon-sensitive endopeptidases J Biol Chem. 2001;276(24):21895-21901.

89. Marr RA, Rockenstein E, Mukherjee A, et al. Neprilysin gene transfer reduces human amyloid pathology in transgenic mice. $J$ Neurosci. 2003;23(6):1992-1996.

90. Eckeman EA, Eckman CB. Abeta-degrading enzymes: modulators of Alzheimer's disease pathogenesis and targets for therapeutic intervention. Biochem Soc Trans. 2005;33(Pt 5):1101-1105.

91. Hersh LB, Rodgers DW. Neprilysin and amyloid beta peptide degradation. Curr Alzheimer Res. 2008;5(2):225-231.

92. Eckman EA, Adams SK, Troendle FJ, et al. Regulation of steady-state beta-amyloid levels in the brain by neprilysin and endothelin-converting enzyme but not angiotensin-converting enzyme. J Biol Chem. 2006;281(41):30471-30478.

93. Authier F, Posner BI, Bergeron JJ. Insulin-degrading enzyme. Clin Invest Med. 1996;19(3):149-160.

94. de Tullio MB, Morelli L, Castaño EM. The irreversible binding of amyloid peptide substrates to insulin-degrading enzyme: a biological perspective. Prion. 2008;2(2):51-56.

95. Eckman EA, Reed DK, Eckman CB. Degradation of the Alzheimer's amyloid beta peptide by endothelin-converting enzyme. J Biol Chem 2001;276(27):24540-24548.

96. Eckman EA, Watson M, Marlow L, Sambamurti K, Eckman CB. Alzheimer's disease beta-amyloid peptide is increased in mice deficient in endothelin-converting enzyme. $J$ Biol Chem. 2003;278(4): 2081-2084

97. Yan P, Hu X, Song H, et al. Matrix metalloproteinase-9 degrades amyloid-beta fibrils in vitro and compact plaques in situ. $J$ Biol Chem. 2006;281(34):24566-24574

98. Liao MC, Van Nostrand WE. Degradation of soluble and fibrillar amyloid beta-protein by matrix metalloproteinase (MT1-MMP) in vitro. Biochemistry. 2010;49(6):1127-1136.

99. Hernandez-Guillamon M, Mawhirt S, Fossati S, et al. Matrix metalloproteinase 2 (MMP-2) degrades soluble vasculotropic amyloid-beta E22Q and L34V mutants, delaying their toxicity for human brain microvascular endothelial cells. J Biol Chem. 2010; 285(35):27144-27158.

100. Van Nostrand WE, Porter M. Plasmin cleavage of the amyloid beta-protein: alteration of secondary structure and stimulation of tissue plasminogen activator activity. Biochemistry. 1999;38(35): 11570-11576.

101. Tucker HM, Kihiko M, Caldwell JN, et al. The plasmin system is induced by and degrades amyloid-beta aggregates. $J$ Neurosci. 2000;20(11):3937-3946.
102. Jacobsen JS, Comery TA, Martone RL, et al. Enhanced clearance of Abeta in brain by sustaining the plasmin proteolysis cascade. Proc Natl Acad Sci U S A. 2008;105(25):8754-8759.

103. Leissring MA, Farris W, Chang AY, et al. Enhanced proteolysis of beta-amyloid in APP transgenic mice prevents plaque formation, secondary pathology, and premature death. Neuron. 2003;40(6):1087-1093.

104. Caccamo A, Oddo S, Sugarman MC, Akbari Y, LaFerla FM. Ageand region-dependent alterations in Abeta-degrading enzymes: implications for Abeta-induced disorders. Neurobiol Aging. 2005;26(5): 645-654.

105. Tucker HM, Kihiko-Ehmann M, Wright S, Rydel RE, Estus S. Tissue plasminogen activator requires plasminogen to modulate amyloid-beta neurotoxicity and deposition. J Neurochem. 2000;75(5): $2172-2177$.

106. Ledesma MD, Da Silva JS, Crassaerts K, Delacourte A, De Strooper B, Dotti CG. Brain plasmin enhances APP alpha-cleavage and Abeta degradation and is reduced in Alzheimer's disease brains. EMBO Rep. 2000;1(6):530-535.

107. Yepes M, Lawrence DA. New functions for an old enzyme: nonhemostatic roles for tissue-type plasminogen activator in the central nervous system. Exp Biol Med (Maywood). 2004;229(11): 1097-1104

108. Ledesma MD, Abad-Rodriguez J, Galvan C, et al. Raft disorganization leads to reduced plasmin activity in Alzheimer's disease brains. EMBO Rep. 2003;4(12):1190-1196.

109. Strickland S. Tissue plasminogen activator in nervous system function and dysfunction. Thromb Haemost. 2001;86(1):138-143.

110. Barker-Carlson K, Lawrence DA, Schwartz BS. Acyl-enzyme complexes between tissue-type plasminogen activator and neuroserpin are short-lived in vitro. J Biol Chem. 2002;277(49):46852-46857.

111. Davies BJ, Pickard BS, Steel M, Morris RG, Lathe R. Serine proteases in rodent hippocampus. J Biol Chem. 1998;273(36):23004-23011.

112. Tsirka SE, Rogove AD, Bugge TH, Degen JL, Strickland S. An extracellular proteolytic cascade promotes neuronal degeneration in the mouse hippocampus. J Neurosci. 1997;17(2):543-552.

113. Siao CJ, Fernandez SR, Tsirka SE. Cell type-specific roles for tissue plasminogen activator released by neurons or microglia after excitotoxic injury. $J$ Neurosci. 2003;23(8):3234-3242.

114. Chen ZL, Strickland S. Neuronal death in the hippocampus is promoted by plasmin-catalyzed degradation of laminin. Cell. 1997;91(7):917-925.

115. Tsirka SE, Rogove AD, Strickland S. Neuronal cell death and tPA. Nature. 1996;384(6605):123-124.

116. Wang YF, Tsirka SE, Strickland S, Stieg PE, Soriano SG, Lipton SA. Tissue plasminogen activator (tPA) increases neuronal damage after focal cerebral ischemia in wild-type and tPA-deficient mice. Nat Med. 1998;4(2):228-231.

117. Nagai N, De Mol M, Lijnen HR, Carmeliet P, Collen D. Role of plasminogen system components in focal cerebral ischemic infarction: a gene targeting and gene transfer study in mice. Circulation. 1999;99(18):2440-2444.

118. Nicole O, Docagne F, Ali C, et al. The proteolytic activity of tissue-plasminogen activator enhances NMDA receptor-mediated signaling. Nat Med. 2001;7(1):59-64.

119. Yepes M, Sandkvist M, Coleman TA, et al. Regulation of seizure spreading by neuroserpin and tissue-type plasminogen activator is plasminogen-independent. J Clin Invest. 2002;109(12):1571-1578.

120. Medina MG, Ledesma MD, Domínguez JE, et al. Tissue plasminogen activator mediates amyloid-induced neurotoxicity via Erk1/2 activation. EMBO J. 2005;24(9):1706-1716.

121. Lijnen HR, Silence J, Lemmens G, Frederix L, Collen D. Regulation of gelatinase activity in mice with targeted inactivation of components of the plasminogen/plasmin system. Thromb Haemost. 1998; 79(6):1171-1176.

122. Kim YH, Park JH, Hong SH, Koh JY. Nonproteolytic neuroprotection by human recombinant tissue plasminogen activator. Science. 1999;284(5414):647-650. 
123. Yepes M, Sandkvist M, Moore EG, Bugge TH, Strickland DK, Lawrence DA. Tissue-type plasminogen activator induces opening of the blood-brain barrier via the LDL receptor-related protein. $J$ Clin Invest. 2003;112(10):1533-1540.

124. Madani R, Hulo S, Toni N, et al. Enhanced hippocampal long-term potentiation and learning by increased neuronal expression of tissue-type plasminogen activator in transgenic mice. EMBO J. 1999;18(11):3007-3012.

125. Calabresi P, Napolitano M, Centonze D, et al. Tissue plasminogen activator controls multiple forms of synaptic plasticity and memory. Eur J Neurosci. 2000;12(3):1002-1012.

126. Rogove AD, Siao C, Keyt B, Strickland S, Tsirka SE. Activation of microglia reveals a non-proteolytic cytokine function for tissue plasminogen activator in the central nervous system. J Cell Sci. 1999;112 (Pt 22):4007-4016.

127. Pawlak R, Rao BS, Melchor JP, Chattarji S, McEwen B, Strickland S. Tissue plasminogen activator and plasminogen mediate stress-induced decline of neuronal and cognitive functions in the mouse hippocampus. Proc Natl Acad Sci U S A. 2005;102(50):18201-18206.

128. Dimova EY, Samoylenko A, Kietzmann T. Oxidative stress and hypoxia: implications for plasminogen activator inhibitor-1 expression. Antioxid Redox Signal. 2004;6(4):777-791.

129. Popa-Wagner A, Fischer B, Platt D, Schmoll H, Kessler C. Delayed and blunted induction of mRNA for tissue plasminogen activator in the brain of old rats following pentylenetetrazole-induced seizure activity. J Gerontol A Biol Sci Med Sci. 2000;55(5):B242-B248.

130. Cacquevel M, Launay S, Castel H, et al. Ageing and amyloid-beta peptide deposition contribute to an impaired brain tissue plasminogen activator activity by different mechanisms. Neurobiol Dis. 2007; 27(2):164-173.

131. Perego M, Palmieri G, Nazzari M. Effects of oral and parenteral 3-GS administration on blood lipids and haemostatic parameters in atherosclerotic hyperlipaemic patients. In: Lenzi S, Descovich CG, editors. Atherosclerosis: Etiopathogenesis, Clinical Evaluation and Therapy. Bologna: Editrice Compositori; 1982:457-463.

132. Bonacci C, Crolle G, Olivi A, et al. Effetti del sulodexide in pazienti anziani con vasculopatia arteriosclerotica cerebrale. [Effects of sulodexide in elderly patients with artherosclerotic cerebral vascular disease.] Acta Gerontol. 1986;36(3-4):228-235. Italian.

133. Capone-Braga M, Tellini L, Boncompagni L, Bettoni M, Burali A, Bensi A. Approccio terapeutico con sulodexide in pazienti con vasculopatia aterosclerotica a varia localizzazione. [Sulodexide treatment approach in patients with atherosclerotic vascular disease with various localizations.] Clin Ter. 1987;120(1): 25-31. Italian.

134. Cospite M, Milio G, Ferrara F, et al. Double-blind study of the pharmacological effect of sulodexide in patients with multiple atherosclerotic vascular disease. Eur Rev Med Pharmacol Sci. 1985;7:97-106.

135. Bonanno G, Bonaccorso R, Dell'ali C, Salanitri G. Sulodexide in the treatment of atherosclerosis: a controlled clinical trial. Acta Therapeutica. 1985;11:87-98.

136. Postiglione F, Pisani P, Gisonni P, et al. Il sulodexide nella terapia delle vasculopatie. [Sulodexide in the therapy of vasculopathies.] Clin Ter. 1986;117(3):223-231. Italian.
137. Santus G, Sottini G, Lombardi G, Rozzini R, Inzoli R. L'uso del sulodexide nei vasculopatici cerebrali con dislipidemia e/o diabete:contributo clinico statistico. [Role of sulodexide in cerebral vasculopathy with dyslipidemia and/or diabetes: clinical statistical contribution.] Atherosclerosis and Cardiovascular Diseases. 1984; 415:20. French.

138. Conti L, Re F, Lazzerini F, et al. Glycosaminoglycan polysulfate (Ateroid) in old-age dementias: effects upon depressive symptomatology in geriatric patients. Prog Neuropsychopharmacol Biol Psychiatry. 1989;13(6):977-981.

139. Ban TA, Morey LC, Aguglia E, et al. Glycosaminoglycan polysulfate in the treatment of old age dementias. Prog Neuropsychopharmacol Biol Psychiatry. 1991;15(3):323-342.

140. Ban TA, Morey LC, Fjetland OK, et al. Early manifestations of dementing illness: treatment with glycosaminoglycan polysulfate. Prog Neuropsychopharmacol Biol Psychiatry. 1992;16(5):661-676.

141. Pollack SJ, Sadler II, Hawtin SR, Tailor VJ, Shearman MS. Sulfated glycosaminoglycans and dyes attenuate the neurotoxic effects of betaamyloid in rat PC12 cells. Neurosci Lett. 1995;184(2):113-116.

142. Parnetti L, Mari D, Abate G, et al. Vascular dementia Italian sulodexide study (VA.D.I.S.S.). Clinical and biological results. Thromb Res. 1997;87(2):225-233.

143. Aisen PS, Saumier D, Briand R, et al. A Phase II study targeting amyloid-beta with 3APS in mild-to-moderate Alzheimer disease. Neurology. 2006;67(10):1757-1763.

144. Lasierra-Cirujeda J, Coronel Granado P. A study on the safety, efficacy, and efficiency of sulodexide compared with acenocoumarol in secondary prophylaxis in patients with deep venous thrombosis. Angiology. 2006;57(1):53-64.

145. Chung TK, Funk MA, Baker DH. L-2-oxothiazolidine-4-carboxylate as a cysteine precursor: efficacy for growth and hepatic glutathione synthesis in chicks and rats. $J$ Nutr. 1990;120(2):158-165.

146. Jahoor F, Jackson A, Gazzard B, et al. Erythrocyte glutathione deficiency in symptom-free HIV infection is associated with decreased synthesis rate. Am J Physiol. 1999;276(1 Pt 1):E205-E211.

147. Lyons J, Rauh-Pfeiffer A, Yu YM, et al. Blood glutathione synthesis rates in healthy adults receiving a sulfur amino acid-free diet. Proc Natl Acad Sci U S A. 2009;97(10):5071-5076.

148. Anderson ME, Luo JL. Glutathione therapy: from prodrugs to genes. Semin Liver Dis. 1998;18(4):415-424.

149. Badaloo A, Reid M, Forrester T, Heird WC, Jahoor F. Cysteine supplementation improves the erythrocyte glutathione synthesis rate in children with severe edematous malnutrition. Am J Clin Nutr. 2002;76(3):646-652.

150. Martina V, Bruno GA, Zumpano E, Origlia C, Quaranta L, Pescarmona GP. Administration of glutathione in patients with type 2 diabetes mellitus increases the platelet constitutive nitric oxide synthase activity and reduces PAI-1. J Endocriol Invest. 2001;24(1):37-41.

151. Hsu CH-CH, Yen H, Yin M, Tsai $\mathrm{CH}$, Hsieh $\mathrm{CH}$. Five cysteinecontaining compounds delay diabetic deterioration in Balb/cA mice. J Nutr. 2004;134(12):3245-3249.

\section{Publish your work in this journal}

The Journal of Blood Medicine is an international, peer-reviewed, open access, online journal publishing laboratory, experimental and clinical aspects of all topics pertaining to blood based medicine including but not limited to: Transfusion Medicine; Blood collection, Donor issues, Transmittable diseases, and Blood banking logistics; Immunohematology; Artificial and alternative

\section{Dovepress}

blood based therapeutics; Hematology; Biotechnology/nanotechnology of blood related medicine; Legal aspects of blood medicine; Historical perspectives. The manuscript management system is completely online and includes a very quick and fair peer-review system. Visit http://www.dovepress.com/ testimonials.php to read real quotes from published authors. 